\title{
Correction to: Isolated ascending aorta dilatation is associated with increased risk of abdominal aortic aneurysm
}

Enrique Gallego-Colon ${ }^{1 *}$, Chaim Yosefy ${ }^{1}$, Evgenia Cherniavsky ${ }^{2}$, Azriel Osherov ${ }^{1}$, Vladimir Khalameizer ${ }^{1}$, Xavier Piltz ${ }^{2}$, Marina Pery', Sharon Bruoha ${ }^{1}$ and Jamal Jafari ${ }^{1}$

\section{Correction to: J Cardiothorac Surg 16, 108 (2021) https://doi.org/10.1186/s13019-021-01488-w}

The original article [1] contained typesetting errors in Fig. 1 which have since been corrected.

\begin{abstract}
Author details
${ }^{1}$ Cardiology Department, Barzilai Medical Center Campus, Barzilai University Medical Center, Ben-Gurion University, Ashkelon, Israel. ${ }^{2}$ Department of Medical Imaging, Barzilai University Medical Center, Ben-Gurion University, Ashkelon, Israel.
\end{abstract}

Published online: 09 June 2021

\section{Reference}

1. Gallego-Colon E, et al. Isolated ascending aorta dilatation is associated with increased risk of abdominal aortic aneurysm. J Cardiothorac Surg. 2021;16: 108 https://doi.org/10.1186/s13019-021-01488-w.

The original article can be found online at https://doi.org/10.1186/s13019021-01488-w.

* Correspondence: enrique.gce@gmail.com

${ }^{1}$ Cardiology Department, Barzilai Medical Center Campus, Barzilai University Medical Center, Ben-Gurion University, Ashkelon, Israel

Full list of author information is available at the end of the article

(c) The Author(s). 2021 Open Access This article is licensed under a Creative Commons Attribution 4.0 International License, which permits use, sharing, adaptation, distribution and reproduction in any medium or format, as long as you give appropriate credit to the original author(s) and the source, provide a link to the Creative Commons licence, and indicate if changes were made. The images or other third party material in this article are included in the article's Creative Commons licence, unless indicated otherwise in a credit line to the material. If material is not included in the article's Creative Commons licence and your intended use is not permitted by statutory regulation or exceeds the permitted use, you will need to obtain permission directly from the copyright holder. To view a copy of this licence, visit http://creativecommons.org/licenses/by/4.0/ The Creative Commons Public Domain Dedication waiver (http://creativecommons.org/publicdomain/zero/1.0/) applies to the data made available in this article, unless otherwise stated in a credit line to the data. 